https://doi.org/10.17816/MAJ191S145-47

\title{
MAST CELLS AFTER BONE MARROW AUTOTRANSPLANTATION
}

\author{
O.V. Vorobyova, L.A. Lyubovtseva, E.A. Guryanova, N.E. Gimaldinova
}

The Department of General and Clinical Morphology and Forensic Medicine Chuvash State University

I.N. Ulyanova, Cheboksary, Russia

\section{ТУЧНЫЕ КЛЕТКИ ПОСЛЕ АУТОТРАНСПЛАНТАЦИИ КОСТНОГО МОЗГА}

\author{
О.В. Воробьева, Л.А. Любовцева, Е.А. Гурьянова, Н.Е. Гималдинова \\ Кафедра общей и клинической морфологии и судебной медицины \\ ФГБОУ ВО «Чувашский государственный университет им. И.Н. Ульянова», Чебоксары
}

\begin{abstract}
Purpose: to study bone marrow mast cells in mice after autotransplantation. Materials and methods. Mast cells and sulphatedness degree of heparin mucopolysaccharide in the bone marrow were identified using Unna staining with polychromatic toluidine blue. Study results. Data on mast cells distribution in the bone marrow after autotransplantation in 40 minutes and in 2 hours were analyzed. Two types of mast cells' reaction to autologous bone marrow introduction were identified: sequential degranulation and exocytosis. As a result, secretion of mast cells causes production of biologically active substances in the microenvironment of a mast cell; these substances form chains and conglomerates from granules, changes in the number of which can contribute to changing the process of mitotic division. According to morphological criteria three populations of mast cells were identified: small-sized cells, with blue-colored nuclei stained orthochromatically and located asymmetrically; metachromatic oval-shaped cells with a nucleus located in the centre; large, degranulated, gamma-metachromatic mast cells. Most part of mast cells in bone marrow smears is presented by integral forms. Heparin in mast cells takes part in regulating metabolism in the bone marrow after autotransplantation.
\end{abstract}

Keywords: mast cells; autotransplantation; the bone marrow.

Цель - изучить тучные клетки костного мозга мышей после аутотрансплантации. Материал и меmoды. При окраске полихромныим толуидиновым синим по Унна выявляли тучные клетки и степень сульфатированности мукополисахарида гепраина в костном мозге. Результаты исследований. Проанализированы данные о распределении тучных клеток в костном мозге после аутотрансплантации через 40 минут и через 2 часа. Выявлено два типа реакции ТК на введение собственного костного мозга: поэтапная дегрануляция и экзоцитоз. В результате этого секреция ТК ведет к выделению биологически активных веществ в микроокружение тучной клетки, которые образуют цепочки и конгломераты из гранул, изменение количества которых может способствовать изменению процесса митотического деления. По морфологическим критериям выявлено три популяции ТК: клетки мелких размеров, с наличием голубых ядер, окрашенные ортохромно, расположенные ассиметрично; клетки метахроматичные овальной формы, с центрально расположенным ядром; крупные, дегранулированные, гамма-метахроматичные. Большая часть ТK в мазках костного мозга представлена цельными формами. Гепарин тучных клеток принимает участие в регуляции метаболизма в костном мозге после аутотрансплантации.

Ключевые слова: тучные клетки; аутотрансплантация; костный мозг.

Introduction. Mast cells are highly specialized neuroimmune cells of the extracellular matrix, containing in the cytoplasm multilayer heparin granules associated with biologically active substances. The main aspect of mast cell regulatory function seems to be their role as mediators between the nervous and immune systems. The full extent of the influence of the relationship between mast cells and nerves on homeostasis is unclear $[1,2]$. A distinctive feature of mast cells is their ability to exert a multidirectional effect on the same process, which makes it possible to consider them as regulators of tissue homeostasis [3]. The purpose of the study is to study the state of the TC and sulfation ("maturity") of heparin in bone marrow cells after autotransplantation.

Material and research methods. Bone marrow smears were examined in mice after bone marrow autotransplantation (25) and controls (5). Under ether anesthesia in mice, $1 \mathrm{ml}$ of bone marrow was removed, diluted in $2 \mathrm{ml}$ of isotonic solution, then $1 \mathrm{ml}$ of the obtained suspension of bone marrow cells was injected into the tail vein of the same mice. Heparin sulfation was detected in TC, KM hematopoietic cells.

Results and its discussion. After KM autotransplantation in 40 minutes in KM smears, the number of mast cells is increased by 1.7 times. The detectable TKs are compact, have dimensions of up to $6 \mu \mathrm{m}$, perhaps these are young cell forms. Granules with unpainted granules, i.e. not containing heparin. However, in these cells, heparin is determined in the nucleus and in the intergranular space of the cytoplasm. Cells are large in size up to $18 \mu \mathrm{m}$, adipocytes with a cricoid orthochromic nucleus are located around them. Visually deter- 
mined contacts of TK with other hematopoietic cells. This combination of different cell types is rare in intact animals and often, as revealed, after autotransplantation. Two types of reaction of TK to the introduction of their own bone marrow are determined: gradual degranulation and exocytosis. As a result, the secretion of TK leads to the release of biologically active substances into the microenvironment of the mast cell, which form chains and conglomerates of granules, changing the number of which may contribute to a change in the process of mitotic division $[5,6]$. According to morphological criteria, three TC populations are identified: one is of small size from 5.4 to $7.1 \mu \mathrm{m}$, with blue nuclei, orthochromically colored, arranged asymmetrically; others are oval, with a centrally located core from 8.3 to 11 microns, metachromatic; third - degranulated to 16 microns, gamma metachromatic. Most of the TC in CM smears were represented by whole forms $(75.87 \%)$, partially $(16.65 \%)$ and totally $(7.48 \%)$ degranulated cells were also detected. 2 hours after autotransplantation, the number of TC increases by 2.6 times $(p<0.01)$. Small sizes of TC from 5.4 to 7.1 microns are detected, with asymmetrically located orthochromic nucleus (young forms). In some megakaryocytes, heparin sulfate increases. The cytoplasm of a part of megakaryocytes has gamma-chromatic staining, which is obviously associated with the accelerated maturation of these cells. Heparin sulfate increases in the cells of the erythroid, basophilic series (beta-metachromasia), which is obviously associated with increased differentiation of the cells of these series [3-7]. Studies have shown that TCs are sensitive markers that react to $\mathrm{CM}$ transplantation both by changing the degree of sulfation ("maturity") of the heparin contained in them, and by changing the number of cells mainly, as revealed by the young forms of TC. The main amount of heparin is released from TK into the extracellular space after autotransplantation of CM, its role in the binding of neuroamines in the intercellular space increases [5]. The obtained results confirm the involvement of heparin TC in the local modulation of biogenic metabolism.

\section{References}

1. Kutukova NA, Nazarov PG, Kudryavtseva GV, Shishkin VI. Mast cells and aging. Advances in gerontology. 2016;29(4):586-593.

2. Forsythe P. Mast Cells in Neuroimmune Interactions. Trends Neurosci. 2019;42(1):43-55. https:// doi.org/10.1016/j.tins.2018.09.006.

3. Gimaldinova NE, Ignatieva EN, Lyubovtseva LA, et al. The effects of cycloferon on the distribution of neuroamines in bioamine-containing structures of the spleen. Journal of New Medical Technologies. 2018;25(3):101-106.

4. Guryanova EA, Lyubovtseva LA, Shabukova AA. The study of the functional state of mast cells of the skin in the field of acupuncture points after acupuncture. Nizhny Novgorod Medical Journal. 2008;(5):110.

5. Vorobeva OV. Dynamics of morpho-functional conditions of cellular programmed differentiation in bone marrow as a hemopoietic organ. Zhurnal anatomii i gistopatologii. 2017;6(2):26-29.

6. Vorobeva OV. Neurally mediated biogenic amines in bone marrow structures in allografting. Morfologicheskie vedomosti. 2016;24(4):89-91.

7. Chesnokova NP. Haematopoiesis and its regulation at various stages of differentiation of hematopoietic bone marrow cells. Saratov Journal of medical scientific research. 2012;8(3):711-719. 